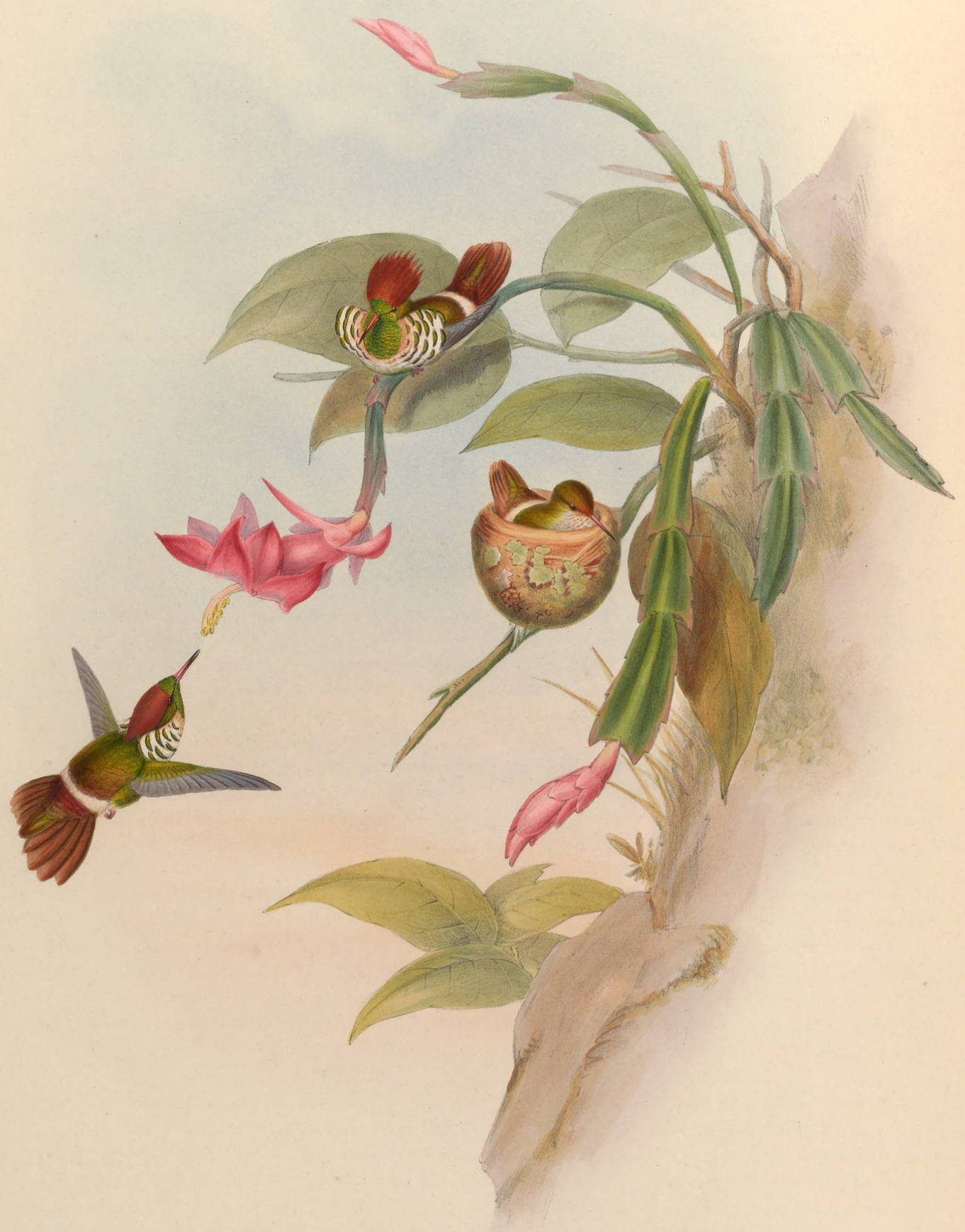




\section{LOPHORNIS MAGNIFICUS.}

\section{Frilled Coquette.}

Trochilus magnificus, Vieill. 2nde Edit. du Nouv. Dict. d'Hist. Nat., tom. vii. p. 367, et tom. xxiii. p. 428. pl. G 36. fig. 3.-Ib. Ency. Méth. Orn., part ii. p. 559.-Ib. Ois. dor., tom. iii. pl. 8.-Temm. Pl. Col. 229. fig. 2.-Jard. Nat. Lib. Humming Birds, vol. i. pp. 119 \& 121. pls. 19 \& 20.-Pr. Max. Beitr. zur Nat. von Bras., p. 79.

decorus, Licht. Verz. der Doubl., p. 14.

Colibri helios, Spix, Av. Sp. Nov. Bras., tom. i. p. 81. tab. lxxxii. fig. 2.

Ornismya magnifica, Less. Man. d'Orn., tom. ii. p. 80.

strumaria, Less. Hist. Nat. des Ois. mou., pp. xl \& 143. pls. $42 \& 43$.

Lophornis strumaria, Less. Ind. Gen. et Syn. des Ois. du Genre Trochilus, p. xli.-Ib. Traité d'Orn., p. 285.

Mellisuga magnifica, Gray and Mitch. Gen. of Birds, vol. i. p. 113, Mellisuga, sp. 88.

Lophornis magnificus, Bonap. Consp. Gen. Av., p. 83, Lophornis, sp. 2.-Ib. Rev. et Mag. de Zool. 1854, p. 257.

Bellatrix magnifica, Reichenb. Aufz. der Colibris, p. 12.

THE discovery of this beautiful little species of Lophornis is said to have been made by M. De Lalande, the celebrated French traveller, at the period of whose visit to Brazil and for some time afterwards the bird was very rarely to be met with in our collections; such, however, is no longer the case, for its proper habitat having been ascertained, it is killed and skinned by the negroes, and the skins, bearing a certain market value, are sent to this country and to France in great numbers. Its native country is Brazil; and the localities in which it appears to be most abundant are the provinces of Rio de Janeiro and Minas Geraes. M. De Lalande procured examples in the forests bordering the river Paraiba, to the north of Rio de Janeiro; and MM. Quoy and Gaimard obtained others among the moderately dense vegetation bordering the torrents at the foot of the Organ Mountains. The notes transmitted to me by Mr. Reeves of Rio de Janeiro merely mention that it inhabits that province and Minas Geraes, but unfortunately give no account of its habits.

The nest is a small round cup-shaped structure, composed of a rufous-coloured fungus-like substance, coated externally with cobwebs and fine vegetable fibres, and decorated with small pieces of lichens.

Like the other members of the genus, this species has the sides of the neck adorned with beautiful snowywhite plumelets; but these plumelets differ in form, being shorter and broader, and are moreover crossed by a band of luminous green at the extremity, instead of having a spot of that colour at the tip.

The sarne difference which exists between the sexes of the other species also occurs with the present, the female being destitute of the conspicuous decorations of the male.

The male has a broad band across the forehead, face and throat luminous green; head and crest dark chestnut-red ; upper surface and wing-coverts bronzy green; wings purplish brown; a band of white across the lower part of the back; upper tail-coverts bronzy brown ; central tail-feathers bronzy green; lateral ones deep chestnut-red, bordered with brownish black; on each side the neck a series of broad white feathers advancing forward and meeting immediately beneath the green gorget; each of those on the sides of the neck crossed at the tip with a band of luminous green ; under surface bronzy green ; bill flesh-red at the base, deepening into black at the point.

The female has the head and upper surface bronzy green; a narrow band of white across the lower part of the back; upper tail-coverts tipped with bronzy red; tail deep fawn-colour, crossed towards the extremity by a broad dusky band; throat rufous; under surface bronzy green.

The Plate represents two males and a female with the nest, all of the natural size. 


\section{$2 \mathrm{BHL}$ Biodiversity Heritage Library}

Gould, John. 1854. "Lophornis magnificus, Frilled Coquette. [PI. 119]." A monograph of the Trochilidae, or family of humming-birds 3, https://doi.org/10.5962/p.316928.

View This Item Online: https://www.biodiversitylibrary.org/item/109468

DOI: https://doi.org/10.5962/p.316928

Permalink: https://www.biodiversitylibrary.org/partpdf/316928

\section{Holding Institution}

Smithsonian Libraries

\section{Sponsored by}

Smithsonian Institution Libraries

\section{Copyright \& Reuse}

Copyright Status: NOT_IN_COPYRIGHT

This document was created from content at the Biodiversity Heritage Library, the world's largest open access digital library for biodiversity literature and archives. Visit BHL at https://www.biodiversitylibrary.org. 